\title{
Performance Indicators for Quality, Innovation, and Competitiveness : A Survey on the Saudi Manufacturing Sector
}

\author{
Khalid Al-Shuaibi ${ }^{1,2}$, Mohamed Zain ${ }^{2} \&$ Norizan Kassim² \\ ${ }^{1}$ Dean of Business School- Rabigh, King Abdulaziz University, Jeddah, Saudi Arabia \\ ${ }^{2}$ Faculty of Economics \& Administration, King Abdulaziz University, Jeddah, Saudi Arabia \\ Correspondence: Khalid Al-Shuaibi, Dean of Business School-Rabigh, King Abdulaziz University, Jeddah, \\ Saudi Arabia. E-mail:kshuaibi@ hotmail.com
}

Received: November 6, 2015

Accepted: December 14, 2015

Online Published: January 25, 2016

doi: 10.5539/ibr.v9n2p99

URL: http://dx.doi.org/10.5539/ibr.v9n2p99

\begin{abstract}
This study examines the relationships between quality, innovation, competitiveness, and financial performance of firms. Data were obtained from a questionnaire survey involving 223 Saudi companies and were analyzed using Structural Equation Modeling (SEM). The results indicate that innovation positively influences quality and the latter has a significant positive influence on the competitiveness of the firms. As expected, both quality and innovation indicators have an indirect influence on the financial performance of the firms through competitiveness. Therefore, this study discovers the important mediating role played by competitiveness in the positive effects of quality and innovation on financial performance of the firms. Finally, we found significant positive effects of competitiveness on financial performance of the firms. Managerial implications are also discussed.
\end{abstract}

Keywords: quality, innovation, competitiveness, financial performance, manufacturing firms, Saudi Arabia

\section{Introduction}

In the current era of globalization barriers to trade between countries have been reduced, the ability of firms to remain be competitive, grow and prosper is of immense importance to a country's economy. In order to remain competitive, firms needs to focus on their ability to satisfy their customers. Hence, it is important for them to continue to offer quality products and services besides being innovative in their operations. It is essential that we understand how firms assess their performance through such indicators as quality and innovation initiatives or programs being implemented in their organization. There are many benefits both in terms of revenues and costs that can be derived from higher quality products or services (Gummersson, 1993).

The importance of innovation in firms' competition has been well recognized by researchers (Politis, 2005; Terziovski, 2002; Zain, 1995). Innovation comprises not just new products or services, but also new ways of doing things, new markets, new source of funds, etc. (Hine \& Ryan, 1999; Johannessen, Olsen, \& Lumpkin, 2001; Nyström, 1990; Schumpeter, 1934). Zain and Rickards (1996) have found that those firms who are able to introduce minor and major changes in their organization are the ones who are adaptable to changes in the external environment. Such firms create an internal environment conducive to creativity and innovation. It can be assumed that innovative firms are in a better position to face competition from other firms in the industry and have better market performance. Thus, this research determines the causal links between quality and innovation indicators on competitiveness and performance of organizations since, these linkages have not yet been investigated in the past.

The main objective of this research is to investigate quality and innovation practices in Saudi Arabia, an-oil-based economy with strong government control over major economic activities. The country possesses $18 \%$ of the world's proven petroleum reserves, ranks as the largest exporter of petroleum, and plays a leading role in OPEC, although its influence has waned in recent years. It is therefore interesting to investigate the indicators of quality, innovation, and competitiveness of the manufacturing firms in Saudi Arabia in order to examine their contribution to the country's economy. Hence, the specific objectives of the research are:

- To examine the relationships between quality indicators, innovation adoptions, competitiveness and 
performance of manufacturing firms in Saudi Arabia.

- To investigate whether quality indicators of firms positively influence the competitiveness and performance of the firms in Saudi Arabia?

- To investigate whether innovation indicators of firms positively influence the competitiveness and performance of the firms in Saudi Arabia?

- To investigate whether innovation indicators of firms positively influence the quality indicators of the firms in Saudi Arabia?

So far there has not been any research done in Saudi Arabia on the subject matter of this research. The result of this research will produce new knowledge about the roles of quality, innovation, and other "winning order factors" in contributing positively to the firms' performance and competitiveness in Saudi Arabia, where this concept is naive.

\section{Conceptual Framework and Hypotheses}

This study suggests a conceptual model deduced from the literature. The innovation, quality, competitiveness and performance (hereinafter, it is referred to as "IQCP") model consists of the following dimensions; Innovation, Quality, Competitiveness, and Financial Performance (Figure: 1). The background literature and detail descriptions of the dimensions with their possible linkages with each other are described later.

\subsection{Quality Indicators}

Over the years, organizations throughout the world have introduced and implemented many quality initiatives, programs, and innovations in their efforts to improve their performance and to make them more competitive. Nowadays, very few firms can afford to ignore such programs (e.g., TQM) in their organization (Dean \& Bowen, 1994). For example, many researchers (e.g., Ahire, Golhar, \& Waller, 1996; Flynn, 1994; Mehra \& Joyal, 2011; Samson \& Terziovski, 1999) have found strong and positive relationships between implementation of quality programs and organizational performance.

In Australia, Prajogo and Sohal (2003) have found that a quality program (TQM) significantly and positively relates to both product quality and product innovation performance. They also found significant causal relationship between quality performance and innovation performance, which indicates that achievement of one aspect of performance could impact the other. In addition to quality regarded as a "qualifying criterion" for competitiveness (Hill, 1985), there are many other factors (such as speed, dependability, flexibility, cost, etc.) collectively known as "winning order criteria" should be considered by firms in order to remain competitive (Bolwijn \& Kumpe, 1990; Hamel \& Prahalad, 1994; Slack, Chambers, \& Johnston, 2010; Tidd, Bessant, \& Pavitt, 1997). Slack et al. (2010) defined quality characteristics or indicators of a product or service in terms of: (1) functionality, i.e. how well the product/service does its job; (2) appearance, i.e. its aesthetic appeal, look, feel, etc.; (3) reliability, i.e. the consistency of its performance over time; (4) durability, i.e. its total; useful life; (5) recovery, i.e., how easy it is for any problems with the product/service can be resolved, and; (6) contact, i.e., the nature of person-to-person contact that might occur. It is also very important that these characteristics are measurable in terms of a variable or an attribute. Thus, our first two hypotheses are:

$\mathbf{H}_{\mathbf{1}}$ : Quality (product functionality, appearance, reliability, durability, recovery, and contact) of firms positively influences the competitiveness of the firms.

$\mathbf{H}_{2}$ : Quality (product functionality, appearance, reliability, durability, recovery, and contact) of firms positively influences the performance of the firms.

\subsection{Innovation and Competitiveness Indicators}

According to Nyström (1990) innovation is about "the creation of the future". It is the new way of doing things so that a firm can continue to survive, prosper and be adaptable to the ever changing environment. Schumpeter (1934), who is widely recognized among the earliest contributors on the theory associated with innovation (Rickards, 1985) was considered as the 1st person to understand the importance of innovation throughout firms' levels of competition. 


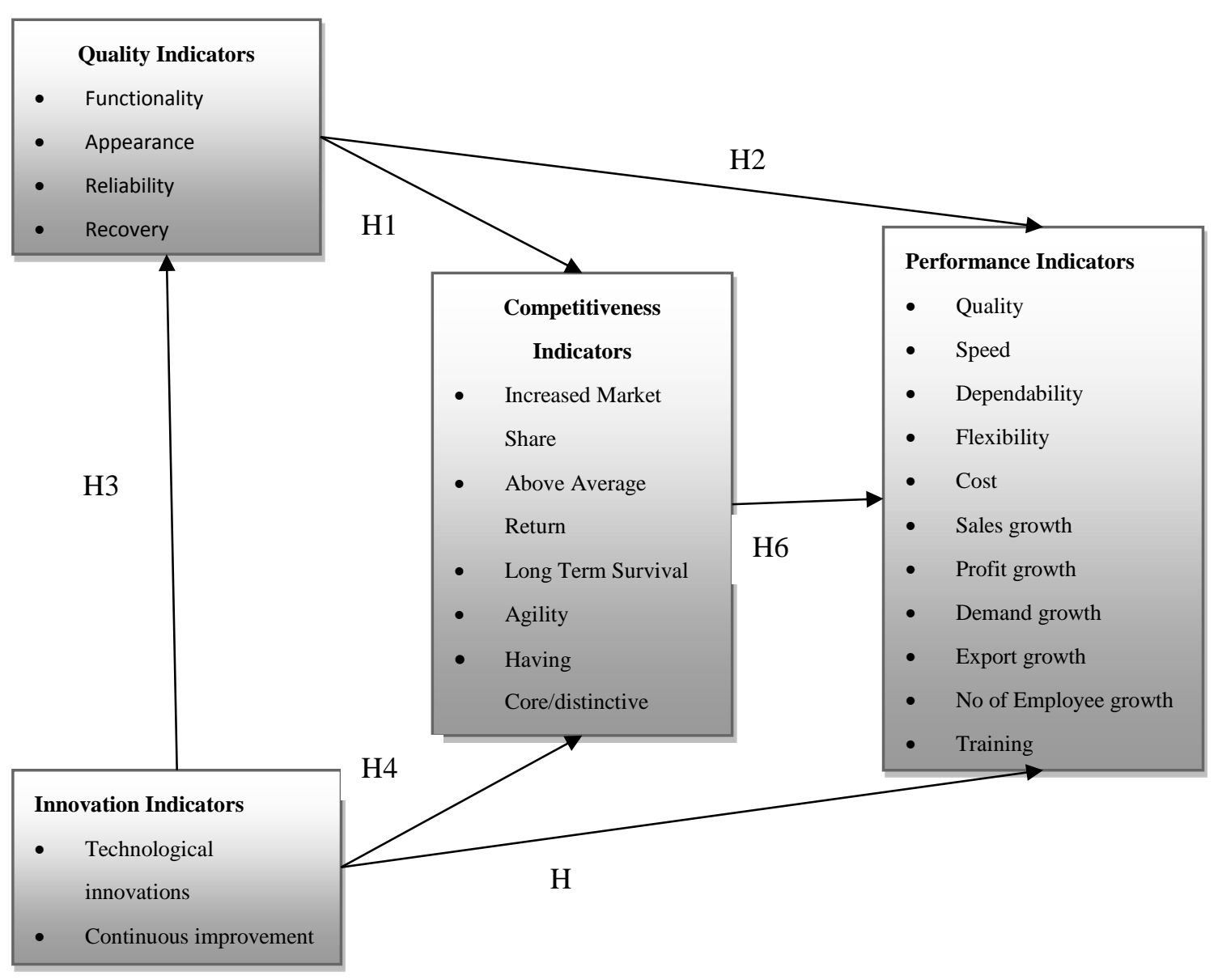

Figure 2. The IQCP model

He asserted that an innovation is not only just new services or products, but also a new market, a new source associated with funds, a new supplier, and so forth (Nyström, 1990). Innovation is certainly found to play an important role throughout contributing and also securing ecological competitive edge in today's agencies (Tushman \& Nadler, 1986). The capacity to innovate is the ability of the organization to adopt or implement new ideas, processes, or products successfully (Burns \& Stalkers, 1961; Hurley \& Hult, 1998). Gaynor (2002) remarked that innovation won't require a genius, but it really does require a system-wide determination to follow unique options. Similarly, Drucker (1998) clearly stated that innovation is work rather than genius understanding that successful innovation requires challenging, focused, in addition to purposeful operates. The innovativeness of the firm's traditions acts in collaboration with various structural properties of the company to help affect it is innovative capacity. Innovativeness of the firm's traditions, when along with its resources along with organizational characteristics, creates a larger capacity to help innovate. Firms having greater impressive capacity could be more successful in answering and adjusting their circumstances and with developing new capacities that permit them to obtain a aggressive advantage in addition to higher functionality (Montes, Moreno, \& Fernández, 2004). One example is, innovativeness is regarded as one of the most critical indicators for a company in a food business to compete in equally domestic in addition to international promotes (Capitanio, Coppola, \& Pascucci, 2014; Grunert et al., 1997; Rama, 1996, 2008).

A couple main varieties of innovation are generally vital to be able to competitiveness involving firms: Major and constant improvement or maybe incremental inventions (Lin \& Chen, 2007; Zain, 1995; Zain \& Rickards, 1996). Radical inventions allow organization to obtain big or maybe drastic improvement with the help of certain technological know-how while incremental creativity enables them to keep about improving their operations which will help prevent them through lagging driving their rivals. Examples involving radical innovation such as a product or a process which resulted from your new technological know-how that changes the way we accomplish things. Incremental inventions include improvements to an existing merchandise, service, or maybe 
process (Terziovski, 2002). While argued by Butler and Collins (1996), firms can perform competitive gain by fitting their business strategies to properly take care of new technological know-how implementation. For example, appropriate use of technology, including information technological know-how, can aid the creativity process and overall competitiveness of organizations (Hine \& Ryan, 1999) as well as making them to be more agile (Zain, Flower, Abdullah, \& Masrom, 2005). Facing intense intercontinental competition, fast technology progression, and customers' getting older expectations, innovation is often a primary procedure by which firms basically adapt (Eisenhardt \& Tabrizi, 1995).

Over time the self-discipline of creativity management has rapidly developed into a separated research field that has been developing fast in terms of attention committed by economics, proper management, and organizational sciences (Trienekens, Lorrie Uffelen, Debaire, \& Omta, 2008). Being a matter involving fact, during the past few decades there were many research that investigated the true secret success components and way to attain reasonably competitive advantage as a result of innovation (Huizenga, 2000). Thus, our 3rd hypothesis will be:

H3: Innovations (radical and continuous improvement) adopted by firms positively influence the Quality of the firms.

The Global Competitiveness Report defines competitiveness as the ability of any country or a firm to create proportionally more wealth as compared to its rivals in Global markets (IMD, 1995). Competitiveness is surely an essential requirement of a firm because of it every single child survive competition. Capitanio et al. (2009) get that creativity plays an important role throughout enhancing firms' competitiveness already in the market. Even though there is no universal explanation of competitiveness, this cardstock defines it as ability of any firm to be able to persuade customers to select it products over these of others (Feurer \& Chaharbaghi, 1994). To become competitive, it is necessary that a firm possesses specific competences (Prahalad \& Hamel, 1990; Singh, Garg, \& Deshmukh, 2008) and become innovative (Simon, 2009; Zain \& Kassim, 2010). In this way, a firm will survive but it is able to continue growing and become sustainable (Searcy, 2011) over a long interval time. It is usually able to increase its market share (Zahra \& Covin, 1993), capable to obtain earlier mentioned average returning (Hitt \& Hoskisson, 2013), and capable to be agile or maybe adaptable to be able to changes even in the turbulent surroundings (Kodish, Gibson, \& Amos 1995; Zain et al., 2004).Thus, our fourth hypothesis is:

$\mathbf{H}_{4}$ : Innovations (radical and continuous improvement) adopted by firms positively influence the competitiveness of the firms.

\subsection{Performance Indicators}

Hine and Ryan (1999) have found that, among small service firms, the more innovative ones are of greater potential value to their industry. Also, Lin and Chen (2007) found that innovation, especially administrative innovation, was the most important factor in explaining sales among Small and Medium Enterprises (SMEs). According to Linder (2008), research in different industries has shown that effective innovation is correlated with better total returns to shareholders and thus to high performance. Innovation has been found to be a major contributor to firm success in both manufacturing and service industries and for small and large firms (see Calantone, Cavusgil, \& Zhao, 2002; Dilk, Gleich, Wald, \& Motwani, 2008; Grawe, Chen, \& Daugherty, 2009; Kandampully, 2002; Laforet \& Tann, 2006; Oke, 2007; Ota, Hazama, \& Samson, 2013). Nonetheless, many past studies of the relationship between innovation and performance have produced mixed results (see Capon, Farley, \& Hoenig, 1990; Chandler Hanks, 1994; Debackere, Van Looy, \& Vliegen 1997; Hine \& Ryan, 1999; Kmieciak, Michna, \& Meczynska, 2012; Li \& Atuagene-Gima, 2001; Low, Chapman, \& Sloan, 2007). Hence, this research represents another try at re-examining this relationship. In Taiwan, Kuei, Madu, and Lin (2001) have observed that high quality-tendency systems tend to perform better than low quality-tendency systems on cost savings in managing supply chain. Also, Madu, Kuei, and Jacob (1996) have found that organizational performance is linked to critical quality factors such as employee satisfaction, customer satisfaction, and employee service quality. Furthermore, Prajogo and Sohal (2002) have found that TQM significantly and positively relates to both product quality and product innovation performance although it appears that the magnitude of the relationship is greater against product quality. They also found significant causal relationships between quality performance and innovation performance suggesting that achievement of one aspect of performance could impact the other. According to Bell and Omachonu (2011) giving emphasis on implementing a documentation system was found to be linked to business performance as measured by return on assets. However, a study on the relationship between TQM practice and organizational performance by Samson and Terziovski (1999) has found that TQM practice intensity helped explaining a significant proportion of variance in performance. They have found that not all of the categories of TQM practice were particularly strong predictors of performance. Also, the results of a study on SMEs in Poland could not confirm that information technology capability has a significant 
moderating effect on the relationship between innovativeness and firm performance (Kmieciak et al., 2012).

According to Richard, Devinny, Yip, and Johnson (undated), organizational performance covers three specific areas of firm outcomes: (1) financial performance (such as profits, return on investment, etc.); (2) market performance (such as market share, sales, etc.); and (3) shareholder return (such as economic added value, total shareholder return, etc.). Thus, performance indicates what the organization has achieved as a result of doing its activities over the years. Thus, our fifth and sixth hypotheses are:

$\mathbf{H}_{5}$ : Innovations (radical and continuous improvement) adopted by firms positively influence the performance of the firms.

$\mathbf{H}_{6}$ : Competitiveness of the firms positively influences their performance.

\section{Research Methodology}

This research was carried out in three stages. In the first stage, a questionnaire was designed to measure quality indicators, innovation indicators, and competitiveness indicators to evaluate the performance indicators. The Stage two involved the sampling, determining the response rate, and the appraisal of the measurement method. Finally, in stage three, Exploratory Factor Analysis (EFA) and Confirmatory Factor Analysis (CFA) were performed before Structural Equation Modeling (SEM) was used to test the causal relationships among the constructs.

\subsection{Measures}

In order to conduct this empirical research, the variables in theoretical model were operationalized using previously validated research instruments (Ekvall et al., 1983; Zain, 1996; Zain \& Kassim, 2010). The survey questionnaire is divided into six parts. Part one contains 17 items pertaining to quality indicators (Slack, Chambers, \& Johnston, 2010); part two consists of 11 items pertaining to innovation indicators (Zain, 1996); part 3 is about 12 items pertaining to performance indicators (Slack et al., 2010); part four consists of 13 items pertaining to competitiveness indicators (Zain \& Kassim, 2010); part five contains 8 questions on financial performance of the firms over the last five-year period prior to the start of the research; and finally, part six lists five items about the respondent's demographic characteristics. All the items listed in the first four parts of the questionnaire were measured with a forced six-point Likert-type scale, anchored from strongly disagree (1) to strongly agree (6). The even numbered rating scales were used to minimize social desirability bias arising from respondents' desires to please the interviewer or to appear helpful to him/her by choosing the midpoint score (Garland, 1991). For part 5, it was measured with a three-point Likert scale; $1=$ below industry average, $2=$ industry average, and $3=$ above average. The questionnaire was originally written in English then translated into Arabic language. To ensure the accuracy of the translation job, the questionnaire was then back-translated into English (Douglas \& Craig, 1983).

\subsection{Sample}

In stage two, the companies operating in Saudi Arabia were selected for this study. Saudi Arabia is a member of the G-20. It is an oil rich country with GDP of \$748.4 billion with a GDP growth of 4\% (Current US\$) (2013 data) (databank.worldbank.org, u. d.). $60.4 \%$ of the country's economy comprises of industrial sector, while $36.4 \%$ comprises of services sector. As an emerging market with a strong economy and growing industrial and services sectors, Saudi Arabia has become an attractive area for an empirical study.

The sample was comprised of Saudi listed companies and large private companies including both manufacturing and services sectors firms. The respondent companies were selected in a stepwise process. In the first step, 165 Saudi companies listed in the Tadawul All-Share Index (TASI) database were selected. Since, a reasonable number of large companies in Saudi Arabia are not listed in the index, therefore stratified sampling method was adopted, we selected 213 large and medium sized companies from the directory of private companies published by the Ministry of Commerce and Industry of Saudi Arabia (Statistical Report, 2012). Thus, the eventual sample for this study comprises of 378 Saudi companies.

\subsection{Survey and Response Rate}

An electronic questionnaire was sent to the CEO/Operations Manager of each firm in the selected sample. Follow up emails were also sent to the companies to ensure a better response rate. Among the questionnaires that were returned to us, those with high missing values were dropped from the sample. Thus, the final sample used in this study comprises a total of 223 companies, giving us a response rate of $58.99 \%$, which is an acceptable response rate for this study (Anderson \& Gerbing, 1988; Hair \& Black, 2010). 


\section{Data Analysis}

The data was analyzed in several steps to test the hypothesized relationships. First of all, the data was checked for normality and multicollinearity as well as for Common Method Bias (CMB). The EFA was then performed to explore the underlying factor structure of the data and also to test whether the model fits the data before conducting Structural Equation Model (SEM). On the basis of pattern matrix obtained from EFA, CFA was performed to examine the measurement reliability and validity as recommended by Anderson and Gerbing (1988). CFA helped to test the model fit of the data to the SEM. After ascertaining the convergent validity and discriminant validity, the hypothesized structural model was tested using SEM (Hair, Black, Babin, \& Anderson, 2010).

\section{Results}

\subsection{Characteristics of the Sample}

Table 1 shows descriptive statistics of the sample. It is evident that the sample is well diversified since there have been responses from managers from both the databases that contributed to our sample.

Table 1. Sample characteristics ( $\mathrm{N}=223)$

\begin{tabular}{llcc}
\hline \multirow{4}{*}{ Type of establishment } & Freq $(\mathrm{N})$ & Percentage \\
\cline { 3 - 4 } & Wholly own by Saudi & 166 & 74.4 \\
& Joint-venture & 48 & 21.5 \\
& Wholly own by foreigner & 9 & 4.0 \\
No. of years in operations & 3-10 years & 41 & 18.4 \\
& 11-20 years & 33 & 14.8 \\
& 21 years and above & 149 & 66.8 \\
No. of products & 1-2 items & 19 & 8.5 \\
& 3-6 items & 34 & 15.2 \\
& 7-12 items & 20 & 9.0 \\
& 13 items and above & 150 & 67.3 \\
& Manufacturing & 137 & 61.4 \\
& Services & 86 & 38.6 \\
\hline
\end{tabular}

\subsection{EFA Result}

All the 61 items in the data were subjected to principle component analysis. The principle component analysis revealed the presence of four components with Eigen values exceeding 1 (Table 2). An inspection of the scree plot showed a clear break after the fourth component. Using Catell's (1966) scree test, it was decided to retain the four components for further investigation. The same procedure was repeated using principal component extraction using promax rotation method. The Promax rotation method was used because the data demonstrated high correlations among the extracted factors. This procedure resulted in a final scale of 46 items belonging to the same four factors, thus confirming that the four-factor solution is the most fitting solution, accounting for $64.4 \%$ of the total variance explained.

In order to check for discriminant validity, pattern matrix was examined. It was found that the retained items loaded sufficiently on their respective factor and they have very low cross loadings on other factors. This shows that they have adequate discriminant validity and convergent validity (Hair et al., 2010). We then named factor one as "competitiveness", factor two as "quality", factor three as "innovation", and finally factor four as "financial" indicators.

\subsection{CFA Result}

In the next step, the research team performed CFA on the data set using maximum likelihood method. Model fits were evaluated using the chi-square $(\chi 2)$, degree of freedom (df), Goodness-of-fit index (GFI), Comparative fit index (CFI), Normed fit index (NFI), and the Root Mean Square Error of Approximation (RMSEA) because of their robustness, stability, and lack of sensitivity to sample size (Hair et al., 2010; Kassim \& Abdullah, 2010). 
Table 2. Factor loadings of the condensed 46 items

Factor 1

The demand for our products/services has been growing steadily 0.96

The market share of our products/services has increased substantially over the last 5 years $\quad 0.85$

$\begin{array}{ll}\text { The market for our products/services is growing very fast } & 0.82\end{array}$

We have been experiencing rapid growth in sales for our business. $\quad 0.81$

We have been experiencing growth in profits from our business $\quad 0.81$

The prospect for long term survival in our business is very good $\quad 0.80$

$\begin{array}{ll}\text { The exports for our products/services has been growing steadily } & 0.74\end{array}$

$\begin{array}{ll}\text { Our business is growing very fast } & 0.72\end{array}$

$\begin{array}{ll}\text { The size of our workforce has been growing steadily } & 0.68\end{array}$

We are strongly believe that our business is sustainable in the long term $\quad 0.65$

We are becoming more and more confidence in our business 0.64

We have been able to obtain above average returns from our business over the last 5 years $\quad 0.61$

We do have our own sustainable core competence in our business $\quad 0.55$

Our training expenditure has been growing steadily 0.82

Factor 2

The customers can depend on our products/services to satisfy their need 0.96

$\begin{array}{ll}\text { Any problem that arises in our products/services can be resolved quickly } & 0.92\end{array}$

We offer the best features in our products/services based on what the customers want 0.78

$\begin{array}{ll}\text { It is very easy for our customers to contact us when such a need arises } & 0.74\end{array}$

$\begin{array}{ll}\text { Our customers do not have to wait a long time to get our services } & 0.73\end{array}$

Our customer service personnel are always friendly and courteous towards our customers $\quad 0.70$

We provide full service to our customers in any matters related to the products/services $\quad 0.67$

We always deliver our products/services fast (speed) $\quad 0.57$

Quality is important to everyone in our organization $\quad 0.56$

Our customer service personnel are always able to answer questions $\quad 0.53$

We always do thing on time (dependability)

We try our best to meet the needs and expectations of our customers $\quad 0.51$

$\begin{array}{ll}\text { Our customers service personnel are always willing to answer questions } & 0.67\end{array}$

Factor 3

We always try to be the first in using the latest technology 1.04

We always look for new ways in managing our employees $\quad 0.82$

$\begin{array}{lr}\text { We always look for the latest technology in our business } & 0.80\end{array}$

$\begin{array}{lr}\text { We always look for new ways in financing our products/services } & 0.78\end{array}$

$\begin{array}{lr}\text { We always look for new ways in obtaining our supplies } & 0.72\end{array}$

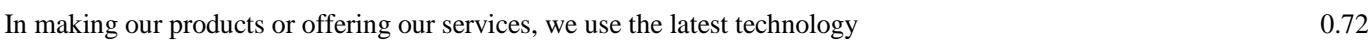

We always look for new ways to improve our products/services $\quad 0.69$

$\begin{array}{ll}\text { We always look for new ways to improve our operations } & 0.61\end{array}$

We continue to conduct research and development $(\mathrm{R} \& \mathrm{D})$ in order to come up with new products/ 0.58

services

Relative to our competitors, our average growth in training expenditure during the last 5 years has 0.54

been

We continue to conduct research and development $(R \& D)$ in order to improve our current

products/services

0.52

The appearance of our products/services are very attractive to our customers

0.45

Factor 4

Relative to our competitors, our average profit growth during the last 5 years has been $\quad 0.82$

Relative to our competitors, our average return on assets during the last 5 years has been $\quad 0.81$

Relative to our competitors, our average return on investment during the last 5 years has been 0.76

Relative to our competitors, our average sales growth during the last 5 years has been $\quad 0.70$

Relative to our competitors, the average growth in demand for our products/services during the 0.60

last 5 years has been

0.55 
has been

Relative to our competitors, our average growth in the number of employees during the last 5 years has been

Corrected Cronbach's $(\alpha)$

Eigenvalue

Cumulative variance explained (\%)

CFA was performed following the procedure suggested by Anderson et al. (1988). 22 items were retained after CFA and adequate model fit was achieved with acceptable fit indices as shown in Table 3. The final acceptable model had acceptable fit indices $(\chi 2 / \mathrm{df}=1.416, \mathrm{GFI}=0.83, \mathrm{CFI}=0.95, \mathrm{NFI}=0.86$, and $\mathrm{RMSEA}=0.06)$ as suggested by Hair et al. (2010).

Table 3. Confirmatory factor analysis summary

\begin{tabular}{|c|c|c|c|}
\hline Variable & Code & Item Description & $\begin{array}{l}\text { Factor } \\
\text { loadings }\end{array}$ \\
\hline \multirow[t]{4}{*}{ Competitiveness } & Perf6 & We have been experiencing rapid growth in sales for our business. & 0.63 \\
\hline & Perf12 & We are becoming more and more confidence in our business. & 0.85 \\
\hline & Comp6 & We do have our own sustainable core competence in our business. & 0.76 \\
\hline & Comp10 & We are able to compete well with our competitors in the market. & 0.68 \\
\hline \multirow[t]{7}{*}{ Quality } & Q4 & We provide full service to our customers in any matters related to the products/services. & 0.70 \\
\hline & Q6 & It is very easy for our customers to contact us when such a need arises. & 0.73 \\
\hline & Q7 & We offer the best features in our products/services based on what the customers want. & 0.81 \\
\hline & Q8 & Quality is important to everyone in our organization. & 0.82 \\
\hline & Q10 & We try our best to meet the needs and expectations of our customers & 0.86 \\
\hline & Perf2 & We always deliver our products/services fast. & 0.79 \\
\hline & Perf3 & We always do thing on time. & 0.80 \\
\hline \multirow[t]{4}{*}{ Innovation } & Inn1 & In making our products/services, we use the latest technology & 0.70 \\
\hline & Inn2 & We always look for the latest technology in our business & 0.68 \\
\hline & Inn6 & We always look for new ways to improve our products/services & 0.82 \\
\hline & $\operatorname{Inn} 7$ & We always look for new ways to improve our operations & 0.90 \\
\hline \multirow[t]{7}{*}{$\begin{array}{l}\text { Fin. } \\
\text { Performance }\end{array}$} & Fin 1 & Relative to our competitors, our Average Sales Growth during the last 5 years has been & 0.73 \\
\hline & Fin 2 & Relative to our competitors, our Average Profit Growth during the last 5 years has been & 0.83 \\
\hline & Fin3 & $\begin{array}{l}\text { Relative to our competitors, our Average Return On Investment during the last } 5 \text { years has } \\
\text { been }\end{array}$ & 0.85 \\
\hline & Fin4 & Relative to our competitors, our Average Return On Assets during the last 5 years has been & 0.89 \\
\hline & Fin5 & $\begin{array}{l}\text { Relative to our competitors, the Average Growth in Demand for our products/services } \\
\text { during the last } 5 \text { years has been }\end{array}$ & 0.81 \\
\hline & Fin6 & $\begin{array}{l}\text { Relative to our competitors, the Average Growth in Exports for our products during the last } \\
5 \text { years has been }\end{array}$ & 0.62 \\
\hline & Fin7 & $\begin{array}{l}\text { Relative to our competitors, our Average Growth in the Number of Employees during the } \\
\text { last } 5 \text { years has been }\end{array}$ & 0.61 \\
\hline
\end{tabular}

\subsection{Validity and Reliability Measurement}

A pilot study was conducted to check the compatibility, and face and content validities of the instrument used in the particular population and culture. The construct validity checks how well the results gained from the use of instrument fit the theory (Cavana, Delahaye, \& Sekaran, 2001) and the content validity is checked by using the constructs that can be validated by peer experts. Both construct and content validities were examined in this study (Hair et al., 2010). The reliability of construct is deemed appropriate and adequate if value remains at least 0.7 for exploratory research and 0.8 for basic research (Nunnally, 1978). The Cronbach alpha and Composite Reliability (CR) were calculated for measuring reliability while Average Variance Extracted (AVE) and Average Shared Variance (ASV) were measured to examine convergent validity and discriminant of the factor structure (Table 4). 
Table 4. Assessment of validity and reliability

\begin{tabular}{llllllll}
\hline Construct & CR & AVE & ASV & 1 & 2 & 3 & 4 \\
\hline 1. Competitiveness & 0.82 & 0.54 & 0.66 & 0.73 & & & \\
2. Quality & 0.92 & 0.62 & 0.55 & $0.93^{*}$ & 0.79 & & \\
3. Innovation & 0.86 & 0.61 & 0.57 & $0.94^{*}$ & $0.83^{*}$ & 0.78 & \\
4. Fin Performance & 0.91 & 0.59 & 0.15 & $0.47^{*}$ & $0.31^{*}$ & $0.37 *$ & 0.77 \\
\hline
\end{tabular}

Note. $\mathrm{CR}=$ Composite reliability; $\mathrm{AVE}=$ Average variance extracted; $\mathrm{ASV}=$ Average shared square variance; diagonal elements are square root of AVE and values below the diagonal are correlations estimates among construct.

For convergent validity, the suggested desirability range for AVE should be higher than 0.5 and greater than ASV and for discriminant validity, AVE should also be greater than ASV (except for Competitiveness) (Hair et al., 2010).

\subsection{SEM Result}

In stage three, in order to test the proposed IQCP model, we estimate the goodness-of-fit as suggested by Hair et.al. (2010). The hypotheses were tested using SEM because this technique provides statistical efficiency and its ability to assess the relationships comprehensively (Hair et al., 2010). Moreover, SEM techniques are particularly appropriate for the study of multiple dependence relationships such as those investigated in this research.

The model of goodness-fit-indices and $p$-statistic are reported in Figure 2. We can thus safely conclude that the model is valid and therefore, we can continue to analyze the outcome of the hypothesized effects. As can be seen in Figure 2, the strength of the relationships among the constructs was represented by the respective standardized path coefficient beta $(\beta)$ with absolute values of 0.44 and above, that is, between medium to large effect as suggested by Cohen (1988). The model explains 28 percent of the variance in financial performance. The results of the analyses are discussed below.

\section{Testing the Hypotheses}

For the first two hypotheses $\left(\mathrm{H}_{1}\right.$ and $\left.\mathrm{H}_{2}\right)$, we found that quality has a positive significant effect $\left(\mathrm{H}_{1}: \beta=0.52\right.$; C.R. = 3.77) on competitiveness. Therefore, $\mathrm{H}_{1}$ is confirmed, but it has insignificant influence on financial performance $\left(\mathrm{H}_{2}: \beta=-0.25\right.$; C.R. $\left.=-1.03\right)$. Therefore, $\mathrm{H}_{2}$ is not confirmed. However, this result also suggests that quality has a strong effect on financial performance, but only through the mediating variable of competitiveness. We take this as a partial support for $\mathrm{H}_{2}$. The model explains 86 percent of the variance in competitiveness (Figure 2). Thus $\mathrm{H}_{3}$ is accepted $\left(\mathrm{H}_{3}: \beta=0.89\right.$; C.R. $\left.=10.18\right)$.

The result reveals that innovation has a large effect on building quality indicators of an organization. The relationship between innovation and competitiveness was also significant, thus $\mathrm{H}_{4}$ is also accepted $\left(\mathrm{H}_{4}: \beta=0.44\right.$; C.R. = 3.12). However, the path between innovation and financial performance was found to be insignificant $\left(\mathrm{H}_{5}\right.$ : $\beta=-0.35$; C.R. $=-1.03$ ). However, the result reveals that, as expected, innovation has a strong effect on financial performance but only through the mediating variable, competitiveness. Thus, $\mathrm{H}_{5}$ is partially confirmed. The model explains 79 percent of the variance in quality (Figure 2). Inspection of the coefficient $\left(\mathrm{H}_{6}: \beta=0.1 .02\right.$; C.R. $=3.36$ ) indicates that, as expected, competitiveness has significant positive impact on financial performance, thus, $\mathrm{H}_{6}$ is accepted. 


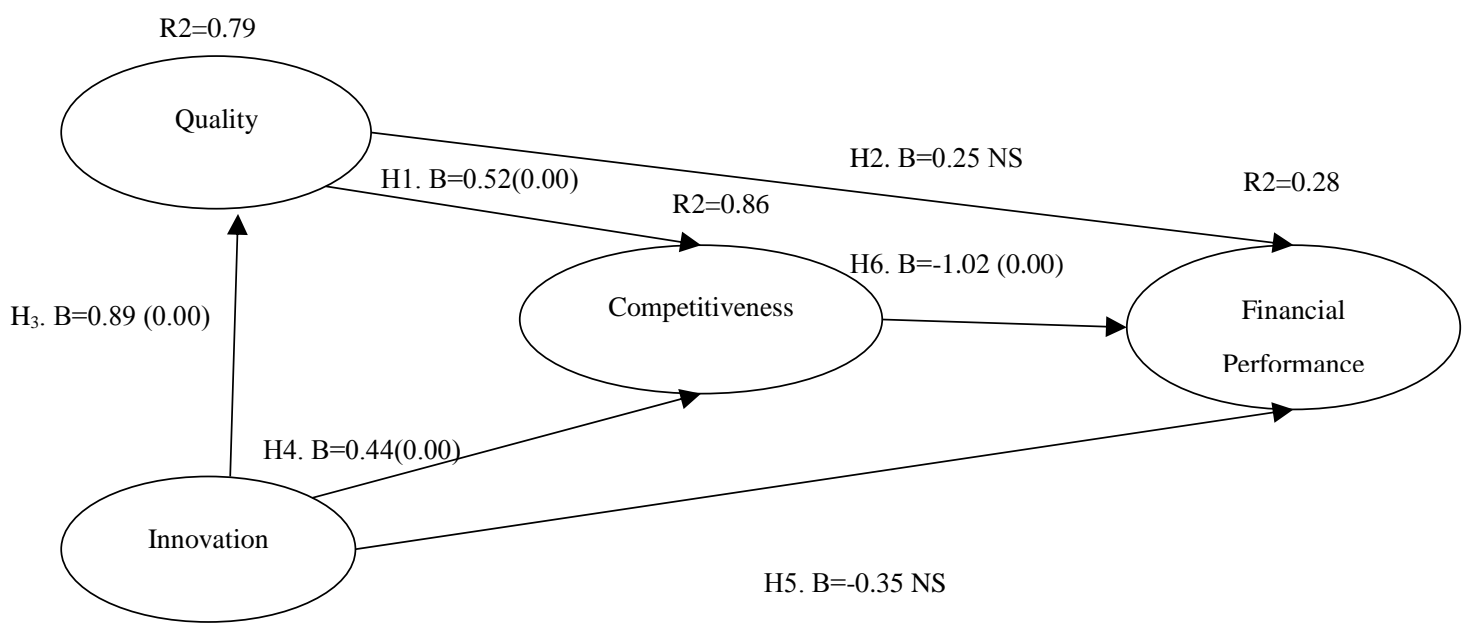

Figure 3. Structural equation model results

For the next three hypotheses $\left(\mathrm{H}_{3}, \mathrm{H}_{4}\right.$ and $\left.\mathrm{H}_{5}\right)$, we found that innovation was positively related to quality. The research hypotheses were confirmed and partially confirmed through SEM in order of their presentation as summarized in Table 5.

Table 5. Summary of results of hypotheses

\begin{tabular}{lll}
\hline & Hypothesis & Supported \\
\hline $\mathrm{H}_{1}$. & There is a significant relationship between quality and competitiveness. & Accepted \\
$\mathrm{H}_{2}$. & There is a significant relationship between quality and financial performance & Partially (only through competitiveness) \\
$\mathrm{H}_{3}$. & There is a significant relationship between innovation and quality & Accepted \\
$\mathrm{H}_{4}$. & There is a significant relationship between innovation and competitiveness & Accepted \\
$\mathrm{H}_{5}$. & There is a significant relationship between innovation and financial performance & Partially (only through competitiveness) \\
$\mathrm{H}_{6}$. & There is a significant relationship between competitiveness and financial performance & Accepted \\
\hline
\end{tabular}

\section{Discussion}

From the results we are able to observe the relationships between quality, innovation, competitiveness, and financial performance of the Saudi firms. First, we found that quality positively and significantly influences the competitiveness of the firms. Second, we found that quality also positively and significantly influences financial performance of the firms but only through the mediating variable of competitiveness. Thus, the importance of a firm to be competitive vis-a-vis it competitors is well demonstrated from this research. Third, we found that innovation has a significant positive influence on quality as well as on financial performance of the firms. Fourth, we found significant positive effects of innovation on financial performance of the firm, but only through the mediating variable of competitiveness. Thus, competitiveness of the firms was again found to be a mediating factor in the financial performance of the firms. Finally, we found significant positive effects of competitiveness on financial performance of the firms. Our findings on the manufacturing firms in Saudi Arabia have confirmed the importance of the various indicators to competitiveness and financial performance of firms, namely, quality (e.g., Lecerf, 2012; Louart \& Martin, 2012; Rong et al., 2015, Hult et al., 2004; Laforet \& Tann, 2006), and innovation (e.g., Denton, 1999; Mole \& Worral, 2001; Pratali, 2003; Szeto, 2000; Zain \& Kassim, 2010; Tsoukatos \& Voulgaris, 2014, Karacaoglu et al., 2012; Tseng et al., 2013) as reported by other researchers in other parts of the world. Furthermore, our study has discovered the important mediating role played by competitiveness in the positive effects of quality and innovation on financial performance of the firms. This is in line with previous research exhibiting the effectiveness of TQM consequential in competitive advantage and improved performance (Al-Otaibi et al., 2015; Salem et al., 2014).

\section{Managerial Implications}

There are number of implications that can be drawn from the findings of this research. First, Saudi managers 
need to ensure that their firms are focused on producing quality products and services to their customers. This enables the firms to be competitive enough to face their rivals in the industry as well as to achieve better financial performance. Second, Saudi managers need to promote innovations in their firms since innovations can positively influence quality of their products/services in addition to the competiveness of their firms. Third, they should understand that the competitiveness of their firm will positively affects the financial performance of their firms. Finally, Saudi managers need to make sure that their firms are competitive as compared to their rivals in their industry since competitiveness mediates the influence of innovation and quality on their financial performance. Hence, they need to develop certain competencies and competitive advantage in their efforts to win competition. Particularly in the Saudi Arabian environment, there is a strong need to ensure the quality of firms to attain competitive advantage resultant into their financial success.

The disclosures from this study have given proof that the conceptualization of quality indicators, innovation indicators, competitiveness and financial performance made in this examination and its subsequent operationalization through the instrument thought seriously about complexities in the degree to which each individual measure or thing added to the general composite scale. This gives a more sensible representation of the data. The fit estimation of the model structure in reminiscent of manner exhibited beneficial as it displays that the indicator variables adding to the general estimation of the outcome variables are significant measures of the fundamental measurement of quality, competitive advantage, and financial performance. Notwithstanding, any instrument can be subjected to further refinement and we encourage typical analysts to corrode improving it further.

\section{References}

Ahire, S. L., Golhar, D. Y., Waller, M. W. (1996). Development and validation of TQM implementation constructs. Decision Sciences, 27, 23-56. http://dx.doi.org/10.1111/j.1540-5915.1996.tb00842.x

Al-Otaibi, F. M. S., Alharbi, M. F., \& Almeleehan, A. (2015). Effect of Total Quality Management Practices Factors on the Competitiveness: Evidence from Saudi Arabia. International Journal of Business and Management, 10, 85. http://dx.doi.org/10.5539/ijbm.v10n5p85

Anderson, J. C., \& Gerbing, D. W. (1988). Structural equation modeling in practice: A review and recommended two-step approach. Psychological Bulletin, 103, 411-423. http://dx.doi.org/10.1037/0033-2909.103.3.411

Bell, M., \& Omachonu, V. (2011). Quality system implementation process for business success. International Journal of Quality \& Reliability Management, 28, 723-734. http://dx.doi.org/10.1108/02656711111150814

Bentler, P. M. (1990). Comparative fit indexes in structural models. Psychological Bulletin, 107, 238-246. http://dx.doi.org/10.1037/0033-2909.107.2.238

Bolwijn, P. T., \& Kumpe, T. (1990). Manufacturing in the 1990s-productivity, flexibility, and innovation. Long Range Planning, 23, 44-57. http://dx.doi.org/10.1016/0024-6301(90)90151-S

Bourne M., Neely A., Platts, K., \& Mills, J. (2002). The success and failure of performance measurement initiatives: Perceptions of participating managers. International Journal of Operations \& Production Management, 22, 1288-1310. http://dx.doi.org/10.1108/01443570210450329

Burns, T., \& Stalker, G. M. (1961). The Management of Innovation. London: Tavistock Publications.

Butler, P., \& Collins, N. (1996). Strategic analysis in political markets. European Journal of Marketing, 30, 25-36. http://dx.doi.org/10.1108/03090569610149773

Calantone, R., Cavusgil, S., \& Zhao, Y. (2002). Learning orientation, firm innovation capability, and firm $\begin{array}{llll}\text { performance. } \quad \text { Industrial } & \text { Marketing }\end{array}$ http://dx.doi.org/10.1016/S0019-8501(01)00203-6

Capitanio, F., Coppola, A., \& Pascucci, S. (2009). Indications for drivers of innovation in the food sector. British Food Journal, 111, 820-838. http://dx.doi.org/10.1108/00070700910980946

Capon, N., Farley, J. U., \& Hoenig, S. (1990). Determinants of financial performance: A meta-analysis. Management Science, 36, 1143-1159. http://dx.doi.org/10.1287/mnsc.36.10.1143

Cavana, R. Y., Delahaye, B. L., \& Sekaran, U. (2001). Applied Business Research: Qualitative and Quantitative Methods. John Wiley \& Sons Australia Limited.

Cohen, J. (1988). Statistical power analysis for the behavioral sciences (2nd ed.). Lawrence Earlbaum Associates, Hillsdale, NJ.

Dean, J. W., \& Bowen, D. E. (1994). Management theory and total quality: Improving research and practice 
through theory development. Academy of Management Review, 19, 392-418.

Debackere, K., Van Looy, B., \& Vliegen, J. (1997). A process view on managing quality during the creation of technical innovations: Lessons from field research. $R \& D$ Management, 27, 197-211. http://dx.doi.org/10.1111/1467-9310.00057

Denton, D. K. (1999). Gaining competitiveness through innovation. European Journal of Innovation Management, 2, 82-85. http://dx.doi.org/10.1108/14601069910269790

Dilk, C., Gleich, R., Wald, A., \& Motwani, J. (2008). State and development of innovation networks: Evidence from the European vehicle sector. Management Decision, 46, 691-701. http://dx.doi.org/10.1108/00251740810873455

Eisenhardt, K. M., \& Tabrizi, B. N. (1995). Accelerating adaptive processes: Product innovation in the global computer industry. Administrative Science Quarterly, 40, 84-110. http://dx.doi.org/10.2307/2393701

Feurer, R., \& Chaharbaghi, K. (1994). Defining Competitiveness: A Holistic Approach. Management Decision, 32, 49-58. http://dx.doi.org/10.1108/00251749410054819

Flynn, B. B. (1994). The relationship between quality management practices, infrastructure and fast product innovation. Benchmarking for Quality Management \& Technology, 1, 48-64. http://dx.doi.org/10.1108/14635779410056886

Franceschini, F., Galetto, M., \& Maisano, D. (2006). Classification of performance and quality indicators in manufacturing. International Journal of Services and Operations Management, 2, 294-311. http://dx.doi.org/10.1504/IJSOM.2006.009862

Garland, R. (1991). The mid-point on rating scale: Is it desirable? Marketing Bulletin, 2, 66-70.

Grawe, S., Chen, H., \& Daugherty, P. (2009). The Relationship Between Strategic Orientation, Service Innovation, and Performance. International Journal of Physical Distribution and Logistics Management, 39(4), 282-300. http://dx.doi.org/10.1108/09600030910962249

Gummersson, E. (1993). Service productivity, service quality and profitability. Proceedings of the 8th International Conference of the Operations Management Association, Warwick, UK.

Grunert, K., Hermsen, H., Meulenberg, M., Kuiper, E., Ottowitz, T., Declerck, F., Traill, B., \& Göransson, G. (1997). A framework for analyzing innovation in the food sector. In B. Traill, \& K. Grunert (Eds.), Product and Process Innovation in the Food Industry (pp. 1-37). Blackie Academic \& Professional, London. http://dx.doi.org/10.1007/978-1-4613-1133-1_1

Hair, J. F., Black, W. C., Babin, B. J., \& Anderson, R. E. (2010). Multivariate Data Analysis. New Jersey: Pearson-Prentice Hall.

Hamel, G., \& Prahalad, C. K. (1994). Competing for the Future. Boston, MA: Harvard Business School Press.

Hine, D., \& Ryan, N. (1999). Small service firms-creating value through Innovation. Managing Service Quality, 9, 411-422. http://dx.doi.org/10.1108/09604529910302109

Hitt, M. A., \& Hoskisson, R. E. (2013). Strategic Management: Concepts: Competitiveness and Globalization. Stamford, CT: Cengage Learning.

Huizinga, E. (2000). Innovation management, how frontrunners stay ahead. Unpublished $\mathrm{PhD}$ thesis, University of Maastricht, Maastricht.

Hult, G. T. M., Hurley, R. F., \& Knight, G. A. (2004). Innovativeness: Its antecedents and impact on business $\begin{array}{llll}\text { performance. } & \text { Industrial } & \text { Marketing }\end{array}$ http://dx.doi.org/10.1016/j.indmarman.2003.08.015

Hurley, F., \& Hult, M. (1998). Innovation, market orientation, and organizational learning: An integration and empirical examination. Journal of Marketing, 62, 42-54. http://dx.doi.org/10.2307/1251742

Johannessen, J., Olsen, B., \& Lumpkin, G. T. (2001). Innovation as newness: What is new, how new, and new to whom? European Journal of Innovation Management, 4, 20-31. http://dx.doi.org/10.1108/14601060110365547

Kandampully, J. (2002). Innovation as the core competency of a service organization: The role of technology, knowledge and networks. European Journal of Innovation Management, 5, 18-26. http://dx.doi.org/10.1108/14601060210415144 
Karacaoglu, K., Bayrakdaroglu, A., \& San, F. B. (2012). The Impact of Corporate Entrepreneurship on Firms' Financial Performance: Evidence from Istanbul Stock Exchange Firms. International Business Research, 6, 163. http://dx.doi.org/10.5539/ibr.v6n1p163

King, N. (1989). Innovation in elderly care organizations: Process and attitude. Unpublished PhD thesis, University of Sheffield, Sheffield.

Kmieciak, R., Michna, A., \& Meczynska, A. (2012). Innovativeness, empowerment and IT capability: Evidence from SMEs. Industrial Management \& Data Systems, 112, 707-728. http://dx.doi.org/10.1108/02635571211232280

Kodish, J. L., Gibson, G. V., \& Amos, J. W. (1995). The development and operation of an agile manufacturing consortium: The case of AAMRC. Proceedings of the Fourth Annual Conference on Models, Metrics and Pilots, 2, Atlanta, Georgia.

Kuei, C., Madu, C. N., \& Lin, C. (2001). The relationship between supply chain quality management practices and organizational performance. International Journal of Quality \& Reliability Management, 18, 864-872. http://dx.doi.org/10.1108/EUM0000000006031

Laforet, S., \& Tann, J. (2006). Innovative characteristics of small manufacturing firms. Journal of Small Business and Enterprise Development, 13, 363-380. http://dx.doi.org/10.1108/14626000610680253

Lanjouw, J. O., \& Schankerman, M. (2004). Patent Quality and Research Productivity: Measuring Innovation with Multiple Indicators. The Economic Journal, 114, 441-465. http://dx.doi.org/10.1111/j.1468-0297.2004.00216.x

Lecerf, M.-A. (2012). Internationalization and Innovation: The Effects of a Strategy Mix on the Economic Performance of French SMEs. International Business Research, 5(2).

Lin, C. Y. \& Chen, M. Y. (2007). Does innovation lead to performance? An empirical study of SMEs in Taiwan. Management Research News, 30, 115-132. http://dx.doi.org/10.1108/01409170710722955

Linder, J. C. (2006). Does innovation drive profitable growth? New metrics for a complete picture. Journal of Business Strategy, 27, 38-44. http://dx.doi.org/10.1108/02756660610692699

Lovelace, K., Shapiro, L., \& Weingart, R. (2001). Maximizing cross-functional new product teams' innovativeness and constraint adherence: A conflict communications perspective. Academy of Management Journal, 44, 779-93. http://dx.doi.org/10.2307/3069415

Louart, P., \& Martin, A. (2012). Small and Medium-sized Enterprises and Their Attitudes towards Internationalization and Innovation. International Business Research, 5(14). http://dx.doi.org/10.5539/ibr.v5n6p14

Low, D. R., Chapman, R. L., \& Sloan, T. R. (2007). Inter-relationships between innovation and market orientation in SMEs. Management Research News, 30, 878-891. http://dx.doi.org/10.1108/01409170710833321

Madu, C. N., Kuei, C., \& Lin, C. (1995). A Comparative Analysis of Quality Practice in Manufacturing Firms in the U.S. and Taiwan. Decision Sciences, 26, 621-635. http://dx.doi.org/10.1111/j.1540-5915.1995.tb01443.x

Madu, C. N., Kuei, C., \& Jacob, R. A. (1996). An empirical assessment of the influence of quality dimensions on oeganizational performance. International Journal of Production Research, 34, 1943-1962. http://dx.doi.org/10.1080/00207549608905006

Maignan, I., \& Ferrell, O. C. (2000). Measuring corporate citizenship in two countries: The case of the United States and France. Journal of Business Ethics, 23, 283-297. http://dx.doi.org/10.1023/A:1006262325211

Maignan, I., Ferrell, O. C., \& Hult, G. T. M. (1999). Corporate citizenship: Cultural antecedents and business benefits. Journal of the Academy of Marketing Science, 27, 455-469. http://dx.doi.org/10.1177/0092070399274005

Mehra, S., Joyal, A. D., \& Rhee, M. (2011). On adopting quality orientation as an operations philosophy to improve business performance in banking services. International Journal of Quality \& Reliability Management, 28, 951-968. http://dx.doi.org/10.1108/02656711111172531

Mole, K., \& Worrall, L. (2001). Innovation, business performance, and regional competitiveness in the West Midlands: Evidence from the West Midlands business survey. European Business Review, 13, 353-364. http://dx.doi.org/10.1108/EUM0000000006198 
Montes, F. J. L., Moreno, A. R., \& Fernández, L. M. M. (2004). Assessing the organizational climate and contractual relationship for perceptions of support for innovation. International Journal of Manpower, 25, 167-180. http://dx.doi.org/10.1108/01437720410535972

Nunnally, J. C. (1978). Psychometric theory. McGraw-Hill.

Nyström, H. (1990). Technological and Market Innovation; Strategies for Product and Company Development. Chichester: John Wiley \& Sons.

Oke, A. (2007). Innovation Types and Innovation Management Practices in Service Companies. International Journal of Operations \& Production Management, 27, 564-587. http://dx.doi.org/10.1108/01443570710750268

Ota, M., Hazama, Y., \& Samson, D. (2013). Japanese Innovation Processes. International Journal of Operations \& Production Management, 33, 275-295. http://dx.doi.org/10.1108/01443571311300773

Podsakoff, P. M., MacKenzie, S. B., Lee, J. Y., \& Podsakoff, N. P. (2003). Common method biases in behavioral research: A critical review of the literature and recommended remedies. Journal of Applied Psychology, 88, 879-903. http://dx.doi.org/10.1037/0021-9010.88.5.879

Politis, J. D. (2005). Dispersed leadership predictor of the work environment for creativity and productivity. European Journal Innovation Management, 8, 182-204. http://dx.doi.org/10.1108/14601060510594693

Prahalad, C. K., \& Hamel, G. (1990). The Core Competence of the Corporation. Harvard Business Review, 79-91.

Prajogo, D. I. (2005). The comparative analysis of TQM practices and quality performance between manufacturing and service firms. International Journal of Service Industry Management, 16, 217-28. http://dx.doi.org/10.1108/09564230510601378

Prajogo, D. I., \& Sohal, A. S. (2003). The relationship between TQM practices, quality performance, and innovation performance: An empirical examination. International Journal of Quality \& Reliability Management, 20, 901-918. http://dx.doi.org/10.1108/02656710310493625

Pratali, P. (2003). Strategic management of technological innovations in the small and medium enterprises. European Journal of Innovation Management, 6, 18-31. http://dx.doi.org/10.1108/14601060310456300

Rama, R. (1996). Empirical study on sources of innovation in international food and beverage industry. Agribusiness, 12 http://dx.doi.org/10.1002/(SICI)1520-6297(199603/04)12:2<123:AID-AGR2>3.0.CO;2-4

123-134.

Rama, R. (2008). Handbook of Innovation in the Food and Drink Industry. New York, NY: The Haworth Press.

Richard, P. J., Devinny, T. M., Yip, G., \& Johnson, G. (n. d.). Measuring Organizational Performance as a Dependent Variable: Towards Methodological Best Practice.

Rickards, T. (1985). Stimulating Innovation. London, UK: Frances Pinter.

Rong, D., Ming, X., \& Limsupanark, J. (2015). The Theoretical Study and Empirical Research Process of Service Innovation: A Literature Review. International Business Research, 8(1). http://dx.doi.org/10.5539/ibr.v8n11p1

Salem, M. I. (2014). Building An Entrepreneurial Economy: Evidence From Developing Countries. International Business \& Economics Research Journal, 13(3), 629-636.

Samson, D., \& Terziovski, M. (1999). The relationship between total quality management practices and

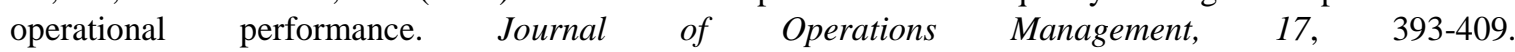
http://dx.doi.org/10.1016/S0272-6963(98)00046-1

Schuurman, H. (1997). Quality Management and Competitiveness-The Diffusion of the ISO 9000 Standards in Latin America and Recommendations for Government Strategies. United Nations, Division of Production, Productivity and Management, Santiago, Chile.

Searcy, C. (2011). Updating corporate sustainability performance measurement systems. Measuring Business Excellence, 15, 44-56. http://dx.doi.org/10.1108/13683041111131619

Simon, H. (2009). Hidden Champions of the Twenty-first Century. The Success Strategies of Unknown World Market Leaders, Springer, New York, NY. http://dx.doi.org/10.1007/978-0-387-98147-5

Singh, R. K., Garg, S. K., \& Deshmukh, S. G. (2008). Competency and performance analysis of Indian SMEs 
and large organizations. Competitiveness Review, 18, 308-321. http://dx.doi.org/10.1108/10595420810920798

Slack, N., Chambers, S., \& Johnston, R. (2010). Operations Management. Harlow, England: Pearson Education Limited.

Statistical Report (2012). Ministry of Commerce and Industry, Saudi Arabia.

Szeto, E. (2000). Innovation capacity: Working towards a mechanism for improving innovation within an $\begin{array}{lllll}\text { inter-organizational } \quad \text { network. The } & \text { TQM }\end{array}$ http://dx.doi.org/10.1108/09544780010318415

Terziosvki, M. (2002). Achieving performance excellence through an integrated strategy of radical innovation and continuous improvement. Managing Business Excellence, 6, 5-14. http://dx.doi.org/10.1108/13683040210431419

Tidd, J., Bessant, J., \& Pavitt, K. (1997). Managing Innovation: Integrating Technological, Market, and Organizational Change. Wiley, Chichester.

Trienekens, J., Van Uffelen, R., Debaire, J., \& Omta, O. (2008). Assessment of innovation and performance in the fruit chain: The innovation-performance matrix. British Food Journal, 110, 98-127. http://dx.doi.org/10.1108/00070700810844812

Tseng, C. Y., Wu, Z. J., \& Lin, C. Y. (2013). Corporate Governance and Innovation Ability: Empirical Study of Taiwanese Electronics Manufactures. International Business Research, 6, 70. http://dx.doi.org/10.5539/ibr.v6n7p70

Tsoukatos, E., \& Voulgaris, F. (2014). Determinants of firm competitiveness: The case of manufacturing firms in Greece. Proceedings of the 7th Euro Med Conference of the Euro Med Academy of Business, Kristiansand, Norway, September 18-19, 2014.

Tushman, M., \& Nadler, D. (1986). Organizing for innovation. California Management Review, 28, 74-92. http://dx.doi.org/10.2307/41165203

Venkatraman, N., \& Ramanujam, V. (1986). Measurement of business performance in strategy research: A comparison of approaches. Academy of Management Review, 11, 801-814.

Weiner, B. J., Alexander, J. A., Shortell, S. M., Baker, L. C., Becker, M., \& Geppert, J. J. (2006). Quality Improvement Implementation and Hospital Performance on Quality Indicators. Health Service Research, 41, 307-334. http://dx.doi.org/10.1111/j.1475-6773.2005.00483.x

Zain, M. (1995). Innovation Implementations in Malaysian Firms: Process, Problems, Critical Success Factors, and Working Climate. Technovation, 15, 375-385. http://dx.doi.org/10.1016/0166-4972(95)96598-N

Zain, M., \& Kassim, N. M. (2010). Innovations and Continuous Improvements and Their Impact on Firm's Performance. International Journal of Social Ecology and Sustainable Development, 1, 32-53. http://dx.doi.org/10.4018/jsesd.2010100104

Zain, M., \& Rickards, T. (1996). Assessing and Comparing the Innovativeness and Creative Climate of Firms. Scandinavian Journal of Management, 12, 109-122. http://dx.doi.org/10.1016/0956-5221(96)00003-6

Zain, M., Rose, R. C., Abdullah, I., \& Masrom, M. (2005). The relationship between information technology acceptance and organizational agility in Malaysia. Information \& Management, 42, 41-51. http://dx.doi.org/10.1016/j.im.2004.09.001

Zahra, S. A., \& Covin, J. (1993). Business strategy, technology policy and firm performance. Strategic Management Journal, 14, 451-478. http://dx.doi.org/10.1002/smj.4250140605

\section{Copyrights}

Copyright for this article is retained by the author(s), with first publication rights granted to the journal.

This is an open-access article distributed under the terms and conditions of the Creative Commons Attribution license (http://creativecommons.org/licenses/by/3.0/). 